\title{
MODEL LAYANAN INFORMASI BERBASIS MULTIMEDIA UNTUK MENINGKATKAN ORIENTASI KARIR MAHASISWA
}

\author{
Hendra Sulistiawan ${ }^{1}$, Kamaruzzaman ${ }^{2}$ \\ ${ }^{1,2}$ Program Studi Bimbingan dan Konseling \\ Fakultas Ilmu Pendidikan dan Pengetahuan Sosial IKIP PGRI Pontianak \\ Jalan Ampera Nomor 88 Pontianak - 78116, Telepon (0561) 748219 Fax. (0561) 589855 \\ Alamat e-mail: ${ }^{2}$ oranecorby@gmail.com
}

\begin{abstract}
Abstrak
Penelitian ini dilakukan berdasarkan temuan empirik yang menunjukkan bahwa permasalahan tentang rendahnya orientasi karir mahasiswa. Oleh karena itu perlu dilakukan upaya atau strategi dalam menyikapi situasi tersebut, sehingga permasalahan terkait dengan orientasi karir yang dialami mahasiswa dapat diatasi dengan baik. Berdasarkan hasil penelitian ditemukan data tentang orientasi karir mahasiswa IKIP-PGRI Pontianak berada pada kategori cukup, untuk itu perlu ditingkatkan. Penelitian ini bertujuan menghasilkan model layanan informasi berbasis multimedia untuk meningkatkan orientasi karir. Hasil penelitian ini menunjukkan bahwa model layanan informasi berbasis multimedia dapat meningkatkan orientasi karir mahasiswa. Faktanya pada uji hipotesis menunjukkan bahwa semua indikator orientasi karir mengalami peningkatan yang signifikan setelah dilakukan uji coba model layanan informasi berbasis multimedia.
\end{abstract}

Kata Kunci: orientasi karir; layanan informasi; multimedia;

\begin{abstract}
This research was conducted based on empirical findings which indicate that the problem is about the low career orientation of students. Therefore an effort or strategy is needed to address the situation, so that problems related to the career orientation experienced by students can be addressed properly. Based on the results of the study, it was found that data on the career orientation of IKIP-PGRI Pontianak students were in a sufficient category, so that it needed to be improved. This study aims to produce a multimedia-based information service model to improve career orientation. The results of this study indicate that a multimediabased information service model can improve student career orientation. The fact that the hypothesis test shows that all career orientation indicators experienced a significant increase after testing the multimedia-based information service model.
\end{abstract}

Keywords: career orientation; information services; multimedia;

\section{PENDAHULUAN}

Pada era ini, penggunaan teknologi tidak hanya untuk membantu pekerjaan manusia, lebih dari itu, perubahan teknologi perlahan namun pasti telah mengubah cara kerja manusia bahkan menggantikan tugas manusia dalam beberapa bidang pekerjaan. Fenomena ini tentu membuat beberapa pihak cemas akan keberlangsungan pekerjaan atau karir di masa yang akan datang. Dominasi teknologi dalam dunia kerja mungkin menjadi mimpi buruk bagi kebanyakan 
pekerja di seluruh dunia. Transisi penggunaan tenaga kerja mulai berubah dari tenaga kerja manusia kepada mesin-mesin dan kecerdasan buatan yang akan memberikan persaingan lebih sengit bagi manusia untuk mendapatkan pekerjaan. Era industri generasi 4.0 pada dasarnya diharapkan untuk menciptakan lapangan kerja yang semakin besar dan potensial, namun realisasi dari transisi bisnis tersebut masih belum terlihat dalam menciptakan lapangan pekerjaan yang pada akhirnya akan semakin memperkecil peluang calon tenaga kerja untuk mendapatkan pekerjaan.

Salah satu upaya yang dilakukan untuk menjawab permasalahan dan tantangan tersebut adalah meningkatkan kesiapan individu untuk menunjang kompetensi diri dalam mendapatkan pekerjaan yang diinginkan. Ketika seseorang menyelesaikan pendidikan formal, selanjutnya mereka dihadapkan kepada tujuan hidup dan memilih pekerjan yang tepat sesuai dengan latar belakang pendidikan, minat dan keahlian yang dimiliki. Mereka juga dituntut membuat perencanaan, persiapan dan pemilihan pekerjaan yang tepat untuk meningkatkan kesiapan dalam memasuki dunia kerja. Hal ini dalam sering disebut dengan orientasi karir.

Berdasarkan penelitian Puspita (2010:45) menunjukkan bahwa rendahnya orientasi di masa depan yang akan memicu pada bertambahnya pengangguran. Keberhasilan mahasiswa dalam pemilihan karir yang tepat tidaklah semudah seperti apa yang dibayangkan dan tidaklah mungkin mahasiswa dapat menentukan karir tanpa informasi yang jelas, karena disadari bahwa untuk memahami kemampuan diri bagi mahasiswa tidaklah mudah dan tidak mungkin muncul dengan sendirinya. Eko A Meinarno (2018) dalam sebuah arikel mengatakan bahwa dalam konteks revolusi industri 4.0 ini, mahasiswa saat lulus menjadi sarjana dengan tingkatan kognitif C4 (menganalisis) tidak pasif. Ia berhadapan dengan dunia yang menuntutnya siap untuk lebih maju. Bukan sekedar maju teknologinya, tapi siap untuk menilai apa kelemahan dan keunggulan saat ini.

Menurut Hurlock (dalam Uman Suherman, 2007:23) pemilihan dan persiapan diri untuk menjalankan suatu pekerjaan atau karir merupakan tugas perkembangan yang penting, sebab karir atau pekerjaan seseorang menentukan berbagai hal dalam kehidupan. Oleh karena itu setiap individu harus memiliki 
orintasi untuk memilih bidang pekerjaan yang akan ditekuni dan jenis pekerjaan yang akan ditekuni. Dalam laporan World Economic Forum's: Future of Jobs Report 2018, perubahan teknologi di era Industri 4.0 disebutkan dapat membawa dampak positif pada sektor bisnis di mana dapat meningkatkan pertumbuhan ekonomi. Tidak hanya itu, kabar baiknya, perubahan teknologi juga memungkinkan tumbuhnya lapangan kerja baru yang tidak diduga sebelumnya. Jadi tidak hanya menghilangkan beberapa bidang pekerjaan, perkembangan teknologi telah membuat penyesuaian terhadap beberapa pekerjaan sehingga memungkinkan munculnya cabang pekerjaan baru, oleh karena itu perlu orientasi terhadap prediksi-prediksi yang akan menentukan ke arah tersebut.

Proses pencapaian kematangan karir, perlu adanya orientasi karir mahasiswa terhadap apa yang diinginkannya kedepan. Orientasi karir yaitu berkenaan dengan tingkat kepedulian yang ditampakkan oleh mahasiswa dalam masalah karir dan keefektifannya dalam menggunakan sumber informasi yang akurat dalam kaitannya dengan pembuatan keputusan karir. Orientasi dapat diartikan sebagai mengarahkan atau mengadakan pengenalan dalam penyesuaian terhadap karir kedepan. Orientasi karir dapat disimpulkan sebagai arah pendirian seseorang sebagai upaya mengenali dan mempersiapkan diri dalam memasuki dunia karir.

Berdasarkan uraian di atas jelas bahwa orientasi karir merupakan sesuatu yang sangat penting bagi mahasiswa. Namun tidak sedikit juga mahasiswa mengalami kesulitan untuk memahami orientasi tersebut. Berdasarkan kenyaatan di lapangan, masih banyak ditemukan mahasiswa yang masih bingung kemana arah karir yang akan ditekuninya kedepan, oleh karena itu tidak sedikit dari mereka yang masih banyak menganggur ketika lulus kuliah. Kebanyakan dari mereka cenderung terorientasi pada karir yang sesuai dengan latar belakag pendidikan mereka. Banyak terdapat mahasiswa yang kurang memahami bahwa orientasi karir merupakan sesuatu yang sangat penting bagi kehidupannya kedepan. Mamat Supriatna (2009:15) mengemukakan bahwa permasalahan karir yang sering terjadi diantaranya: 
1. Beban memiliki pemahaman yang mantap tentang kelanjutan pendidikan setelah lulus;

2. Program studi yang dimasuki bukan pilihan sendiri;

3. Belum memahami jenis pekerjaan yang cocok dengan kemampuan sendiri;

4. Masih bingung memilih pekerjaan yang sesuai dengan minat dan kemampuan;

5. Merasa pesimis bahwa setelah lulus akan mendapatkan pekerjaan yang diharapkan.

Berdasarkan permasalahan karir di atas merupakan gejala rendahnya orientasi seseorang terhadap karirnya. Kebanyakan dari remaja, mereka baru melakukan persiapan diri ketika sudah lulus kuliah. Sehingga mereka cenderung kesulitan dalam menentukan pekerjaan yang mana yang sesuai dengan potensi dan arah karirnya, dan jikapun mereka bekerja kebanyakan mengalami kebingungan untuk menentukan karir di pekerjaan tersebut. Salah satu upaya dalam memberikan informasi dan pemahaman kepada mahasiswa agar memiliki wawasan karir dan orientasi karir yang baik adalah dengan memberikan pelayanan bimbingan dan konseling di perguruan tinggi terutama yang berkaitan dengan bimbingan karir. Salah satu layanan yang dapat digunakan untuk memberikan pemahaman tersebut dapat berupa layanan informasi.

Layanan informasi merupakan salah satu bantuan dalam bimbingan dan konseling berupa informasi-informasi yang diberikan guru bimbingan dan konseling. Depdiknas (2013:15) mengatakan bahwa layanan informasi merupakan "layanan yang memungkinkan mahasiswa menerima dan memahami berbagai informasi (seperti belajar, pergaulan, karier/jabatan, pendidikan lanjutan). Informasi ini diberikan dengan maksud memberikan beberapa informasi terkait dengan kesiapan-kesiapan yang harus dipersiapkan oleh mahasiswa dalam pencapaian karir yang lebih baik.

Pemberian informasi perlu disediakan berbagai bahan penunjang pengembangan keterampilan pribadi, sosial, belajar dan karir, sehingga mahasiswa tidak hanya memperoleh informasi dari buku maupun papan informasi saja. Berbagai bahan tersebut sering disebut dengan media. Seiring dengan 
perkembangan teknologi, media yang konvensional kurang menarik. Oleh karena itu maka perlu dikembangkan suatu media yang nantinya dapat digunakan secara praktis, mudah, dan menarik. Praktis dan mudah ketika digunakan dalam penyampaian informasi. Bahan penjunjang tersebut berupa multimedia. Robin \& Linda (dalam M. Suyanto, 2005:21) menjelaskan multimedia merupakan alat yang dapat menciptakan presentasi yang dinamis dan interaktif yang mengkombinasikan teks, grafik, animasi, audio, dan gambar video. Pengembangan layanan informasi berbasis multimedia bertujuan untuk memudahkan dalam berkomunikasi pada saat penyampaian informasi.

\section{METODE}

Penelitian ini adalah Research and Development yang dikembangkan Borg dan Gall (dalam Sugiyono, 2010), dengan langkah-langkah sebagai berikut: 1) meneliti dan mengumpulkan informasi tentang kebutuhan pengembangan; 2) merencanakan prototipe komponen yang akan dikembangkan termasuk mendefinisikan jenis keterampilan usaha yang akan dikembangkan, merumuskan tujuan, menentukan urutan kegiatan dan membuat skala pengukuran (instrumen penelitian); 3) mengembangkan prototipe awal untuk dijadikan model; 4) melakukan validasi model konseptual kepada para ahli atau praktisi; 5) melakukan ujicoba terbatas (tahap I) terhadap model awal; 6) merevisi model awal, berdasarkan hasil ujicoba dan analisis data; 7) melakukan ujicoba secara luas (tahap II); 8) melakukan revisi akhir atau penghalusan model, apabila peneliti dan pihak terkait menilai proses dan produk yang dihasilkan model belum memuaskan; dan 9) membuat laporan penelitian dan melakukan diseminasi kepada berbagai pihak.

Sembilan langkah tersebut, agar proses pelatihan menjadi lebih efektif dan efisien sesuai, didasarkan pada prinsip-prinsip dan langkah-langkah Borg dan Gall, dengan penyederhanaan langkah-langkah menjadi tiga tahap yaitu: 1) tahap research pendahuluan; 2) tahap pengembangan (development) model, 3) Model akhir. Penyederhanaan langkah tersebut dapat diuraikan sebagai berikut:

1. Penelitian 
Pada tahap ini terdapat beberapa aktivitas utama yang perlu dilakukan yaitu studi literature,dan studi lapangan. Hasil studi dideskrifsikan dengan data faktual di lapangan.

\section{Tahap Pengembangan}

Berdasarkan pada masalah dan potensi yang diketahui dari hasil studi pendahuluan, maka langkah-langkah yaitu : perumusan format desain layanan informasi berbasis media sosial whatsapp, penyusunan/pengembangan layanan informasi berbasis media sosial whatsapp, validasi ahli (ex pert judgement), evaluasi dan perbaikan, uji coba utama (experimental), evaluasi dan penyempurnaan.

\section{Model Akhir}

Setelah melewati tahap pengembangan yang diakhiri dengan evaluasi dan penyempurnaan, tahap berikutnya adalah tahap diseminasi dan sosialisasi.

\section{HASIL DAN PEMBAHASAN}

\section{Gambaran Awal Orientasi Karir}

Untuk mengetahui gambaran orientasi karir mahasiswa dapat dilakukan dengan alat pengumpul data melalui angket. Analisis data yang digunakan dalam penelitian ini adalah data yang dikumpulkan pada setiap kegiatan penelitian. Sebelum hasil penelitian dideskripsikan maka terlebih dahulu hal yang harus dilakukan adalah dengan menentukan kategori hasil angket. Menetapkan kriteria tolok ukur sebagai pedoman untuk mentafsirkan hasil perhitungan data yang diperoleh. Tolok ukur ditetapkan dalam tiga tingkatan, yaitu kategori baik, cukup dan kurang.

\section{Tabel 1. Tolok Ukur}

\begin{tabular}{|c|c|}
\hline KATEGORI & $\%$ SKOR \\
\hline Baik & $66,67 \%-100 \%$ \\
\hline Cukup & $33,34 \%-66,66 \%$ \\
\hline Kurang & $00,00 \%-33,33 \%$ \\
\hline
\end{tabular}


Hasil penyebaran angket tentang orientasi mahasiswa sebelum uji coba model layanan informasi berbasis multimedia. Dari hasil angket yang telah disebarkan pada mahasiswa program studi bimbingan dan konseling tahun akademik 2018/2019 memperoleh persentase secara umum 61,85 \% dengan kategori "cukup".

\section{Proses Penyusunan Model Layanan Informasi Berbasis Multimedia}

Proses penyusun model layanan informasi berbasis multimedia mengacu pada kata kunci yang terdiri diri dari : (1) rasional, (2) konsep kunci, (3) Visi dan Misi, (4) Tujuan, (5) Materi, (6) peran dan fungsi konselor, (7) kualifikasi konselor, (8) anggota kelompok, (9) sifat topik dan suasana interaksi, (10) prosedur kerja layanan informasi berbasis multimedia, (11) tahap-tahap layanan informasi, (12) evaluasi dan tindak lanjut. Model yang telah disusun akan diuji cobakan dengan sebelum di validasi akhir oleh tim ahli.

\section{Perbedaan Orientasi Karir Mahasiswa Setelah Uji Coba Model}

Setelah dilakukan tindakan model layanan informasi berbasis multimedia. Akan dilihat kembali gambaran orientasi karir setelah uji coba model. Untuk mengetahui kondisi tersebut, peneliti menyebarkan kembali angket setelah tindakan. Hasil penyebaran angket setelah diberikan tindakan dalam hal ini uji coba model pada mahasiswa program studi bimbingan dan konseling Tahun Akademik 2018/2019 IKIP-PGRI Pontianak memperoleh persentase secara umum 68,51 \% dengan kategori "BAIK". Sehingga dapat disimpulkan bahwa terdapat peningkatan skor orientasi karir mahasiswa sebelum dan sesudah tindakan sebanyak $6,66 \%$.

\section{Pembahasan}

Orientasi karir calon guru bimbingan dan konseling akan mengarah pada kemampuan guru dalam menyusun rancangan dan melaksanakan strategi layanan yang sesuai dengan kompetensi, karakteristik dan kebutuhan siswa dalam 
belajarnya. Sehingga siswa dapat tercapai ketutantasan belajar secara optimal dan dapat meraih prestasi yang membanggakan. Orientasi karir adalah kompetensi yang mampu menguasai teori dan praksis pendidikan, mengaplikasikan perkembangan fisiologis dan psikologis serta perilaku konseli dan menguasai esensi pelayanan bimbingan dan konseling dalam jalur, jenis, dan jenjang satuan pendidikan.

Orientasi karir guru bimbingan dan konseling yang inovatif harus dimiliki sejak dini yaitu pada calon-calon guru bimbingan dan konseling, sehingga lebih terencana dengan baik. Mereka memiliki waktu yang leluasa untuk mengembangkan diri pada hal-hal yang sifatnya inovatif. Berdasarkan fakta yang terjadi di lapangan masih banyak lulusan guru bimbingan dan konseling yang belum mampu menunjukkan orientasi karir secara baik. Berdasarkan penelitian Puspita (2010:45) menunjukkan bahwa rendahnya orientasi di masa depan yang akan memicu pada bertambahnya pengangguran. Keberhasilan mahasiswa dalam pemilihan karir yang tepat tidaklah semudah seperti apa yang dibayangkan dan tidaklah mungkin mahasiswa dapat menentukan karir tanpa informasi yang jelas, karena disadari bahwa untuk memahami kemampuan diri bagi mahasiswa tidaklah mudah dan tidak mungkin muncul dengan sendirinya. Eko A Meinarno (2018) dalam sebuah arikel mengatakan bahwa dalam konteks revolusi industri 4.0 ini, mahasiswa saat lulus menjadi sarjana dengan tingkatan kognitif C4 (menganalisis) tidak pasif. Ia berhadapan dengan dunia yang menuntutnya siap untuk lebih maju. Bukan sekedar maju teknologinya, tapi siap untuk menilai apa kelemahan dan keunggulan saat ini.

Berdasarkan informasi dari pihak pengguna yaitu sekolah, layanan bimbingan dan konseling yang diberikan oleh guru bimbingan dan konseling masih belum menjukkan hasil yang maksimal. Layanan yang diberikan masih bersifat menoton, konvensional sedangkan yang dihadapinya adalah kaum milineal yang telah mengalami kemajuan, berada pada era disrupsi maupun industri 4.0 .

Era disrupsi adalah suatu zaman yang diwarnai oleh perilaku inovasi, dan perubahan yang sangat cepat yang berdampak pada organisasi dan kehidupan 
masyarakat luas. Pada era ini, suatu badan, lembaga, organisasi, perkumpulan, atau apa namanya yang berbentuk aliansi akan segera mati, bila tidak melakukan perubahan sistem, pola, strategi, cara, metode yang sesuai dengan perkembangan IPTEKS dan kebutuhan masyarakat global. Di pihak lain, kebutuhan masyarakat global berjalan se-arah jarum jam dengan perkembangan IPTEKS.

Seiring perkembangan IPTEKS yang begitu pesat, menjadi tantangan tersendiri dalam meningkatkan kemampuan dalam mempersiapkan orientasi karir. Menurut Hurlock (dalam Uman Suherman, 2007:23) pemilihan dan persiapan diri untuk menjalankan suatu pekerjaan atau karir merupakan tugas perkembangan yang penting, sebab karir atau pekerjaan seseorang menentukan berbagai hal dalam kehidupan. Oleh karena itu setiap individu harus memiliki orintasi untuk memilih bidang pekerjaan yang akan ditekuni dan jenis pekerjaan yang akan ditekuni. Dalam laporan World Economic Forum's: Future of Jobs Report 2018, perubahan teknologi di era Industri 4.0 disebutkan dapat membawa dampak positif pada sektor bisnis di mana dapat meningkatkan pertumbuhan ekonomi. Tidak hanya itu, kabar baiknya, perubahan teknologi juga memungkinkan tumbuhnya lapangan kerja baru yang tidak diduga sebelumnya. Jadi tidak hanya menghilangkan beberapa bidang pekerjaan, perkembangan teknologi telah membuat penyesuaian terhadap beberapa pekerjaan sehingga memungkinkan munculnya cabang pekerjaan baru, oleh karena itu perlu orientasi terhadap prediksi-prediksi yang akan menentukan ke arah tersebut.

Proses pencapaian kematangan karir, perlu adanya orientasi karir mahasiswa terhadap apa yang diinginkannya kedepan. Orientasi karir yaitu berkenaan dengan tingkat kepedulian yang ditampakkan oleh mahasiswa dalam masalah karir dan keefektifannya dalam menggunakan sumber informasi yang akurat dalam kaitannya dengan pembuatan keputusan karir. Orientasi dapat diartikan sebagai mengarahkan atau mengadakan pengenalan dalam penyesuaian terhadap karir kedepan. Orientasi karir dapat disimpulkan sebagai arah pendirian seseorang sebagai upaya mengenali dan mempersiapkan diri dalam memasuki dunia karir. 


\section{SIMPULAN}

Berdasarkan hasil analisis data dalam penelitian ini dapat disimpulkan bahwa model layanan informasi berbasis multimedia untuk meningkatkan orientasi karir mengahdapi era industri 4.0 pada mahasiswa IKIP PGRI Pontianak telah disusun dan diujicobakan dengan baik. Berdasarkan simpulan utama dapat dijabarkan menjadi tiga simpulan sebagai berikut:

1. Orientasi karir mahasiswa IKIP PGRI Pontianak Tahun Akademik 2018/2019 memperoleh kategori "cukup" hasil ini mengindikasikan bahwa mahasiswa belum memiliki orientasi karir secara maksimal.

2. Proses penyusun model layanan informasi berbasis multimedia mengacu pada kata kunci yang terdiri diri dari : (1) rasional, (2) konsep kunci, (3) Visi dan Misi, (4) Tujuan, (5) Materi, (6) peran dan fungsi konselor, (7) kualifikasi konselor, (8) anggota kelompok, (9) sifat topik dan suasana interaksi, (10) prosedur kerja layanan informasi berbasis multimedia, (11) tahap-tahap layanan informasi, (12) evaluasi dan tindak lanjut.

3. Proses pelaksanaan model layanan informasi berbasis multimedia berjalan dengan baik melalui pelaksanaan tindakan dengan 2 siklus penelitian, dengan beberapa tahapan yaitu : perencanaan layanan, pelaksanaan layanan, observasi dan refleksi.

Orientasi karir mahasiswa IKIP PGRI Pontianak Tahun Akademik 2018/2019 setelah diujicobakan model layanan informasi berbasis multimedia yang dikembangkan memperoleh kategori "baik".

\section{DAFTAR PUSTAKA}

Depdiknas. 2013. Kamus Besar Bahasa Indonesia. Jakarta : Balai Pustaka.

Eko A Meinarno. 2018. Kesiapan dan Kontribusi Psikologi untuk Revolusi

Suyanto, M. 2005. Multimedia Alat Untuk Meningkatkan Keunggulan Bersaing. Yogyakarta: CV. Andi Offset.

Sugiyono. 2010. Metode Penelitian. Bandung : Pustaka Setia. 
Uman Suherman. 2007. Konseling Karir Sepanjang Rentang Kehidupan. Bandung: Rizqi Press.

Puspita. 2010. "Efektivitas perencanaan Karir Siswa Kelas XI (Penelitian Terhadap Siswa Kelas XI tahun Pelajaran 2009/2010)". Tesis. Bandung : UPI. 